Davlikanova, O. "Aktualnist vprovadzhennia dualnoi osvity v Ukraini" [The Relevance of the Introduction of Dual Education in Ukraine]. https://www.academia. edu/35288771/

Ofitsiinyi sait Derzhavnoho vyshchoho navchalnoho zakladu «Pryazovskyi derzhavnyi tekhnichnyi universytet». https://pstu.edu/uk/

Ofitsiinyi sait TOV «Metinvest Kholdynh». https://metinvestholding.com/ua

"Polozhennia pro dualnu formu zdobuttia vyshchoi ta fakhovoi peredvyshchoi osvity u DVNZ "PDTU»" [Regulations on the Dual Form of Higher and Professional Higher Education at the State Pedagogical University "PDTU"]. Mariupol, 2019. https://pstu.edu/wp-content/uploads/2021/04/polozhennya-pro-dualnu-formu-zdobuttya-vyshhoyi-ta-fahovoyi-peredvyshhoyiosvity-u-dvnz-pdtu.pdf

Petiukh, V. M. Upravlinnia personalom [HR]. Kyiv: KNEU, 2000.

Predstavnytstvo Fondu im. Fridrikha Eberta v Ukraini (FFE). http://fes.kiev.ua/n/cms/42/
Shelten, A. "Das Konzept der Schlussellqualifikationen in der beruflichen Bildung". Verband der Lehrer an beruflichen Schulen in Bauern - VBB-aktuell, 37, 1988.

"V Ukraini stvoreno pershyi nederzhavnyi hirnycho-metalurhiinyi universytet Metinvest Politekhnika" [The First Non-governmental Mining and Metallurgical University Metinvest Polytechnic Was Established in Ukraine]. Ofitsiinyi sait TOV «Metinvest Kholdynh». https://metinvestholding.com/ua/media/news/v-ukraine-budetsozdan-pervij-negosudarstvennij-gorno-metallurgicheskij-universitet-metinvest-politehnika

"Zvit provedennia monitorynhu ta otsinky rezultatyvnosti realizatsii derzhavnoi rehionalnoi polityky v Ukraini u 2017 rotsi" [Report on Monitoring and Evaluation of the Effectiveness of the Implementation of State Regional Policy in Ukraine in 2017]. https://www. minregion.gov.ua/wp-content/uploads/2018/05/Zvitza-rezultatami-realizatsiyi-derzhavnoyi-regionalnoyipolitiki-v-Ukrayini-u-2017-rotsi1.pdf

UDC 378.4:657.222

JEL: 128; 129; M41; 031; 032

\title{
APPROACHES TO THE FORMATION OF INTANGIBLE RESOURCES BASED ON THE INNOVATIONS INTRODUCTION IN THE HIGHER EDUCATION SYSTEM
}

\author{
๑2021 LABUNSKA S. V., SOBAKAR M. V.
}

UDC 378.4:657.222

JEL: 128; 129; M41; 031; 032

\section{Labunska S. V., Sobakar M. V. Approaches to the Formation of Intangible Resources Based on the Innovations Introduction in the Higher Education System}

The article is aimed at determining approaches to the identification and formation of evaluation indicators as to the production, availability and use of intangible resources, including intellectual ones, as a result of innovative changes in the activities of higher education institutions and their reform on an innovative basis. The role of introduction of innovations in the higher education system for improving the innovative capacity and competitiveness of enterprises and the national economy as a whole is defined. Based on the analysis of statistical data, the need to reform domestic higher education institutions on an innovative basis is identified. The role of implementation of the key performance indicators (KPI) system for identification and evaluation of intangible assets of both intellectual and information nature as a result of innovative changes is substantiated. A general approach to assessing the results of innovations on the basis of giving a tuple look to the model for computing KPI indicators is proposed. The analysis of strategies of innovative development of leading higher education institutions of Ukraine for the implementation of innovative changes is carried out. The identified innovations are grouped into the main types according to the Oslo classification: product-related, technological, marketing and organizational. Each type of innovation is considered in the plane of educational, scientific and international activities. The main directions of innovative changes for each of these groups are allocated and technologies for innovative changes are determined. It is noted how the changes in question affect the formation of the intellectual resource of higher education institutions and business environment entities.

Keywords: identification, innovations, intellectual resource, competitiveness, intangible resources, evaluation, universities.

DOl: $h$ ttps://doi.org/10.32983/2222-4459-2021-10-81-90

Fig.: 3. Formulae: 4. Bibl.: 15.

Labunska Svitlana V. - D. Sc. (Economics), Professor, Professor of the Department of Accounting and Business Consulting, Simon Kuznets Kharkiv National University of Economics (9a Nauky Ave., Kharkiv, 61166, Ukraine)

E-mail: svetlana.lab@gmail.com

ORCID: $h$ ttp://orcid.org/0000-0002-0989-6806

Researcher ID: https://publons.com/researcher/2157010/svitlana-vitalijvna-labunska/

Sobakar Marharyta V. - Postgraduate Student of the Department of Accounting and Business Consulting, Simon Kuznets Kharkiv National University of Economics (9a Nauky Ave., Kharkiv, 61166, Ukraine)

E-mail: rita.vikt@gmail.com

УДК 378.4:657.222

JEL: 128; 129; M41; 031; 032

Лабунська С. В., Собакар М. В. Підходи до формування нематеріальних ресурсів на основі впровадження інновацій у системі вищої освіти Мета статті полягає у визначенні підходів до ідентифікації та формування оцінних показників щодо продукування, наявності та використання нематеріальних ресурсів, у тому числі інтелектуальних, у результаті інноваційних змін у діяльності закладів вищої освіти та їх реформування на інноваційних засадах. Визначено роль запровадження інновацій у системі вищої освіти в підвищенні інноваційної спроможності та конкурен- 
тоспроможності підприємств і національної економіки в цілому. На основі аналізу статистичних даних виявлено необхідність реформування вітчизняних закладів вищої освіти на інноваційних засадах. Обгрунтовано роль упровадження системи KPI (key performance indicators) для iдентифікації та оцінки нематеріальних активів інтелектуально-інформаційного характеру як результатів інноваційних змін. Запропоновано загальний підхід до оцінювання результатів нововведень на основі надання кортежного вигляду моделі розрахунку показників КРІ. Проведено аналіз стратегій інноваційного розвитку провідних закладів вищої освіти України на предмет упровадження інноваційних змін. Виявлені інновації згруповано в основні види за Класифікацією Осло: продуктові, технологічні, маркетингові та організаційні. Кожен вид інновацій розглянуто у площині освітньої, наукової та міжнародної діяльності. Виділено основні напрями інноваційних змін за кожною з таких груп і визначено технології проведення інноваційних змін. Зазначено, яким чином розглянуті зміни впливають на формування інтелектуального ресурсу закладів вищої освіти та суб'єктів бізнес-середовища.

Ключові слова: ідентифікація, інновації, інтелектуальний ресурс, конкурентоспроможність, нематеріальні ресурси, оцінка, університети. Рис.: 3. Формул: 4. Бібл.: 15.

Лабунська Світлана Віталіївна - доктор економічних наук, професор, професор кафедри обліку і бізнес-консалтингу, Харківський національний економічний університет ім. С. Кузнеця (просп. Науки, 9а, Харків, 61166, Україна)

E-mail: svetlana.lab@gmail.com

ORCID: http://orcid.org/0000-0002-0989-6806

Researcher ID: https://publons.com/researcher/2157010/svitlana-vitalijvna-labunska/

Собакар Маргарита Вікторівна - аспірантка кафедри обліку і бізнес-консалтингу, Харківський національний економічний університет ім. С. Кузнеия (просп. Науки, 9а, Харків, 61166, україна)

E-mail: rita.vikt@gmail.com

K nowledge being the basis for intellectual resources and directly depending on the state of the higher education system in the country becomes the main resource for enterprises working in the information economy. Under such conditions, the development level of higher education institutions and their reformation on the basis of innovation becomes a determinant in the development of innovative activities and production of intellectual resources. Creation of intangible resources by higher education institutions includes the following processes: producing learning technologies; creating a network of links with stakeholders to ensure a practical focus of learning services; developing instructional technologies to deal with practical issues arising in the national system of business relations; carrying out fundamental research on innovation which should be put into practice; and establishing relationships with the international community with a view to knowledge and experience exchange. All this makes it possible to start creating an innovative product, namely training highly qualified professionals who become carriers of a unique intangible resource of intellectual and informational nature in the form of acquired knowledge, which can be applied in business and become the basis for developing innovative activity. However, at the moment, when the higher education sector is undergoing reformation, a methodology for identifying and evaluating indicators of achieving the main strategic goal of any higher education institution, i. e. providing quality education and forming an intellectual resource has not been formed yet. No unified system exists for such indicators for process and product innovations, the latter determining the main functions of higher education institutions; the existing indicators

Made within applied research topic No. 0120 U102152 "Development of methodological, model and information support for constructing an innovative type of university on the basis of quality education and anti-corruption". are not standardized, which hinders the processes of establishing and evaluating outcomes, and, consequently, managing them. Therefore, building a system of higher education based on a combination of fundamental and applied knowledge in all types of activity, from organizational and marketing to educational and scientific, facilitates innovative development and gaining competitive advantage at all levels of economic environment and ensures that innovation penetrate the economic process.

Research on the ways to develop the higher education system and on its transformation with regard to innovative change is becoming quite topical due to the crucial importance of universities in the formation of intellectual resources and as a consequence, of the basis for increasing the innovative capacity and competitiveness of the economy. Such scientists as V. O. Zhukova, S. M. Ivanov, N. F. Ilyina, G. P. Klimova, V. D. Nechaev, V. S. Ponomarenko, O. V. Raevneva, L. S. Shevchenko, and others have been engaged in research on innovative development models and creating innovations in the activity of universities. However, the level of developing and implementing innovations remains low, a significant part of higher education establishments do not have strategies for innovative development, or their activities do not allow them to implement their strategic goals.

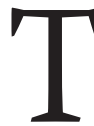
he research on the formation of intangible resources and the role of innovation processes is discussed in the works by such scientists as T. Banasko, I. V. Bryl, N. Yu. Briukhovetska, O. V. Vakun, Yu. Gribovska, S. F. Legenchuk, I. Fedorova and others. Despite a large number of research papers on the issue, the ways of implementing innovative changes in higher education establishments need to be systematized to streamline this process and determine the result of these changes as accumulation of intellectual resources, which will prospectively form the basis for creating intangible resources of business entities. 
The article is aimed at determining approaches to the identification and formation of evaluation indicators for the production, availability and use of intangible resources, including the intellectual ones, as a result of innovative changes in higher education institutions and their reformation on an innovative basis.

$\mathrm{I}$ ntangible resources of intellectual and informational nature become the determinant resource for the activities of enterprises in modern economic conditions that are characterized by development within the information paradigm. With the constant implementation of the results of scientific and technological development in business processes, the possession of intellectual and information assets formed on the basis of intangible resources becomes a competitive advantage in the economic environment. Therefore, effective management of intangible resources becomes an important part of management at modern enterprises. Still, the work of the management system cannot be effective without the evaluation phase, so it is necessary to develop a whole system of indicators to assess the work of an organization with regard to its general strategy. It is such a system of indicators that will make it possible to identify and evaluate all intangible resources, including the intellectual and informational ones, created both in the field of business and in higher education institutions.

Innovations in the field of higher education should be evaluated in all the operation areas. To facilitate this task, all types of activity characteristic for higher education establishments can be divided into main activities and additional services. Focus should be made on the main activities encompassing two main areas: the formation of intangible resources as a result of scientific development (fundamental and applied research) and the provision of educational services, which create intellectual resources in the form of knowledge and skills typical for specialists graduating from higher education establishments. It is the evaluation of the results of innovative implementations in these areas that is key to evaluating the activities of a university.

Intangible resources created as a result of innovations in higher education establishments require the development of special approaches to evaluation, because information and intellectual resources are not always appropriate to be evaluated by identifying their costs included in the prime cost. For example, the results of fundamental and applied research can be evaluated by the cost method based on the cost of all expenses, while all intangible resources related to the quality of educational services and formed on the basis of students' personal qualities and teachers' qualifications cannot be reliably evaluated by using the cost method, as they differ in value. That is, the evaluation of intellectual and information resources that determine the quality of education received requires new approaches due to the fact that such resources are characterized by a great social significance and form the intellectual heritage of a state.
As it has already been mentioned, scientific developments and educational services being the main products of the activity of higher education establishments make up the basis for creating the country's intellectual resource. Intangible resources being the results of applied and fundamental research can be further used both in education (for learning purposes) and in the practices of enterprises. In addition, graduates of higher education establishments, who have a unique intellectual resource (which, in its turn, is the result of quality educational services and the use of scientific and methodological developments in the learning process), are the main resource for economic development in the innovation field. Taking into account the information given above, we can come to conclusion that there is a close relationship between the quality of innovative changes in higher education establishments and the innovativeness of the economy.

A $s$ the development of innovative universities is the key factor for ensuring the competitiveness of economic entities at the macro- and micro-levels, determining promising areas in further education reforms will help to identify reserves to increase innovation potential and create an intellectual and information resource. To do this, we have analyzed and evaluated the development level of the national higher education system and the state of innovation in the domestic economy as compared to those in other states, grounding our research on global rankings of the Global Competitiveness Index according to the method of the World Economic Forum, and the Global Innovation Index using the method created by Cornell University, French Business School INSEAD, and the World Intellectual Property Organization.

The general level of competitiveness of the national economy is among the indicators of innovative development. Inverse relationship is also actual, i.e., the more stable and developed an economy is, the higher are the chances for developing innovative products and creating intellectual resources. According to the World Economic Forum rating, in 2019 Ukraine ranked only the $85^{\text {th }}$ among 141 countries as for the Global Competitiveness Index. Its rating has not changed considerably over the past 10 years: the place it took varied from the $73^{\text {th }}$ (in 2012) to the $89^{\text {th }}$ (in 2010) [14], thus indicating the presence of crisis phenomena in national economic development.

This economic situation requires urgent radical changes aimed at boosting economic growth, which is only possible through promoting the innovative vector of development, which in turn will ensure a qualitatively new level of functioning for the economy in the information paradigm of the world economy. Therefore, we suggest to consider the dynamic pattern in the level of innovation capacity of a country as a factor ensuring economic development and increasing competitiveness. To do this, we have carried out the analysis by the indicators of the country's innovation capacity (sub-index of competitiveness index according to the methodology of the 
World Economic Forum) and by the Global Innovation Index (ranking of the World Intellectual Property Organization, calculated on the basis of approximately 80 indicators grouped into subgroups according to different aspects of innovation) (Fig. 1) [14; 15].

Despite the fact that, as Fig. 1 shows, the indicators of the level of innovation capacity of Ukraine's economy calculated on the basis of data from the competitiveness index ratings and the global innovation index differ due to different calculation methods, similar trends have been identified. It was found out that generally, there is a slight positive trend to improve Ukraine's position as for its innovation level, but during 2011-2020 this indicator remained almost unchanged, and the innovative capacity of the domestic economy is still low (the highest position was the $43^{\text {rd }}$ place in 2018), which in turn negatively affects the state of the country's competitiveness.

Increasing the level of innovation capacity of the country's economy should begin with reforming the higher education system, which is the basis for staffing innovative activity and creating intellectual resources. Analysis of the situation with higher education in Ukraine carried out on the basis of indices of higher education development (which are sub-indices of the Competitiveness Index and the Global Innovation Index) (Fig. 2) shows that Ukraine is not among the leading countries in terms of education, but the latest trend is that the country is gradually improving its position in these rankings (in 2020, it took the $32^{\text {nd }}$ place among 131 countries).

Tn addition, an integral assessment of the state of universities' development is their positioning in world rankings, the main of which is QS World University. The ranking of domestic higher education establishments, which is determined on the basis of places taken by the top 3 universities in the country (according to the World Intellectual Property Organization (see Fig. 2)) in the ranking of QS World University indicates the low quality of higher education in Ukraine. According to this indicator, Ukraine in 2020 ranked the 49th among 131 countries, and in recent years there has been a decline in the country's position in the ranking [15].

Analysis of the data given in Fig. 1 and Fig. 2 once again confirms the correlation between the development

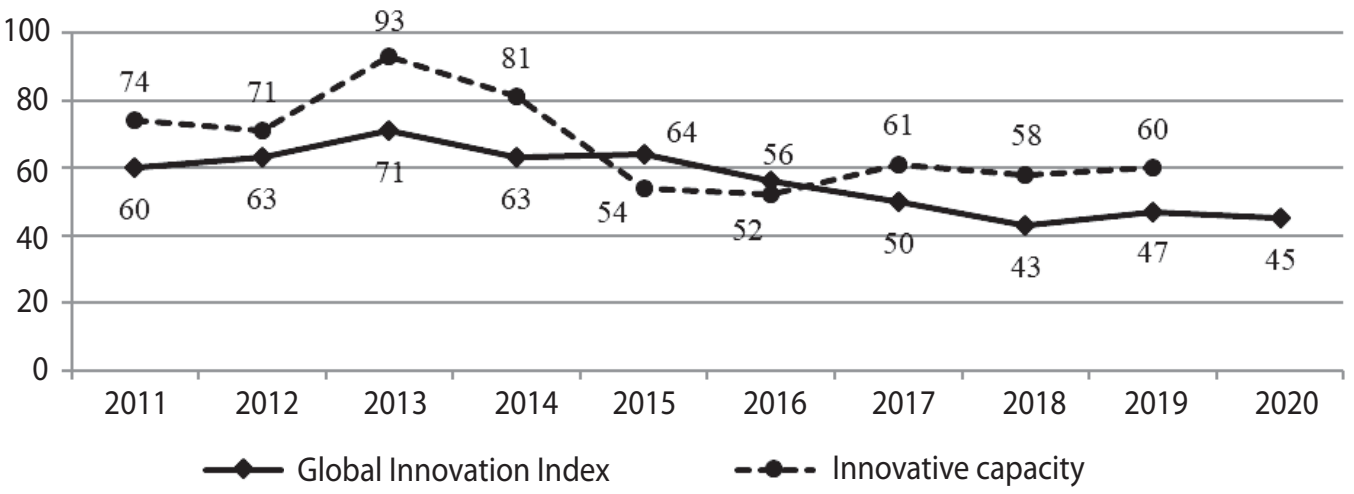

Fig. 1. Ukraine's position according to the level of innovation development

Source: made by the authors on the basis of $[14 ; 15]$.

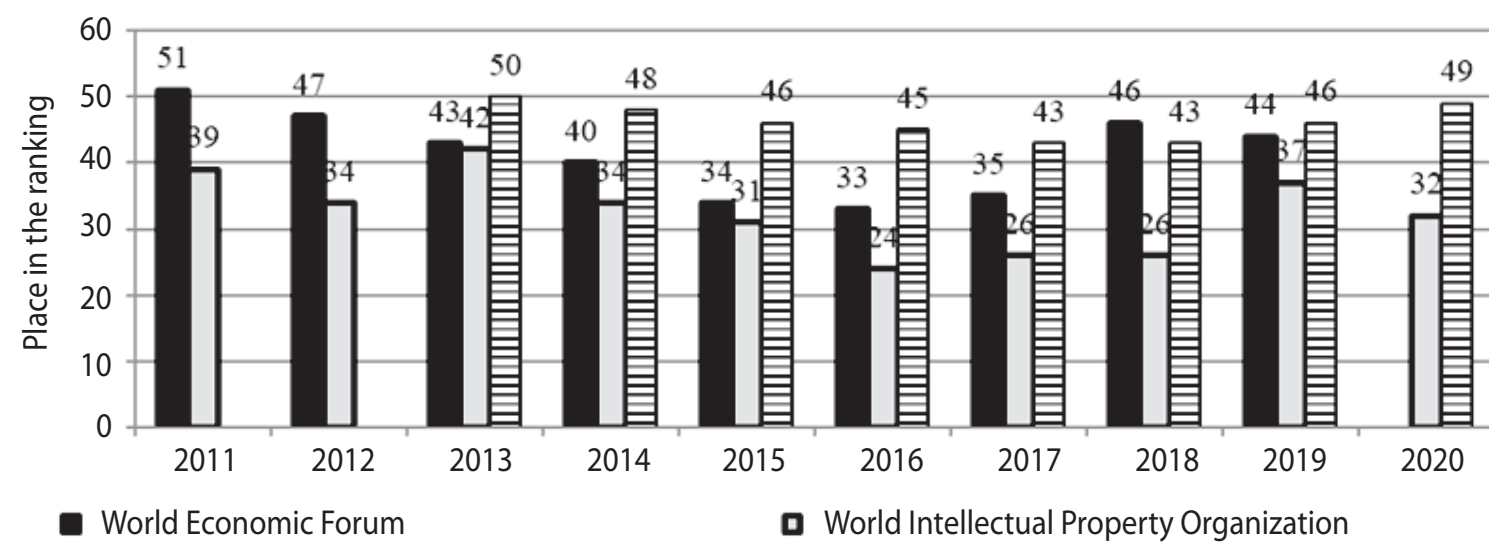

曰 University ranking, average rating top-3 HEE

Fig. 2. Dynamics of Ukraine's position as for the level of higher education development according to the World Economic Forum and the World Intellectual Property Organization

Source: formed by the authors on the basis of $[14 ; 15]$. 
level of the national economy and higher education. Thus, similar trends and dynamic patterns in these areas can be seen.

The considered indicators of Ukraine's positioning in the world by specific components of higher education point to the unsatisfactory development level of the national higher education system and the necessity to reform it in order to provide higher level educational services and transform the role of universities from being the subject of educational services to becoming the driving force of economic development and innovation provision.

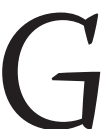
iven the positioning of Ukraine's innovation capacity in international ratings and the state of the country's higher education, the formation of an intellectual resource suitable for developing innovative activity requires higher education institutions to be transformed into innovative universities. To this end, the strategic task should lie in introducing innovative changes in the activities of universities, and on their basis it would be possible to form intangible resources, including the intellectual ones, which will be further involved in the activities of economic entities. Such changes involve a set of ideas, tools and technologies, which should result in bringing the process and results of educational activities to a qualitatively new level. Hence, the main difference between innovations in education and business environment, as education gives the priority to intangible innovations, ideological ones included, that form an intellectual resource.

In this regard, the ways of forming intangible resources in Ukraine's higher education system are determined on the basis of analyzing development strategies used by domestic universities as for implementing innovative changes. The object of the study is made up by the development strategies of Ukraine's 10 leading universities, including 7 universities mentioned in the ranking of QS World University for 2022. They are: V. N. Karazin
Kharkiv National University [11], Taras Shevchenko Kyiv National University [1], National Technical University "Kharkiv Polytechnic Institute" [7], National Technical University of Ukraine "Igor Sikorsky Kyiv Polytechnic Institute" [12], Sumy State University [8], Lviv Polytechnic National University [6], Ivan Franko Lviv National University [4], Vadym Hetman Kyiv National Economic University [10] (which has the status of a research university), Simon Kuznets Kharkiv National University of Economics [9] and State Institution of Higher Education "Uzhgorod National University" [2].

The analysis technique presented in Fig. 3 involves defining the implementation of innovation according to the Oslo Classification, which divides innovation into such groups as organizational, marketing, technological and product innovation [13].

1 The next stage of detailing innovative changes is their analysis within the Triple Helix model, i.e. the distribution of each innovation type among the three main activities of higher education establishments: educational (running of the learning process), scientific (production of new knowledge), and innovative activity (commercialization of knowledge). This list should be supplemented by international activities, which is now becoming increasingly important for the functioning of higher education establishments due to the informatization of society and the growing need for experience and knowledge exchange.

The process of implementing innovative changes should be accompanied by operational determination of the innovation level and strategic goals, which can be achieved by reforming the management system of higher education establishments through introducing performance identification in the KPI system. KPIs (key performance indicators) reflect the performance of an organization and are used to support the process of achieving its strategic and tactical goals. Such indicators are the basis for monitoring the activities of an organization at

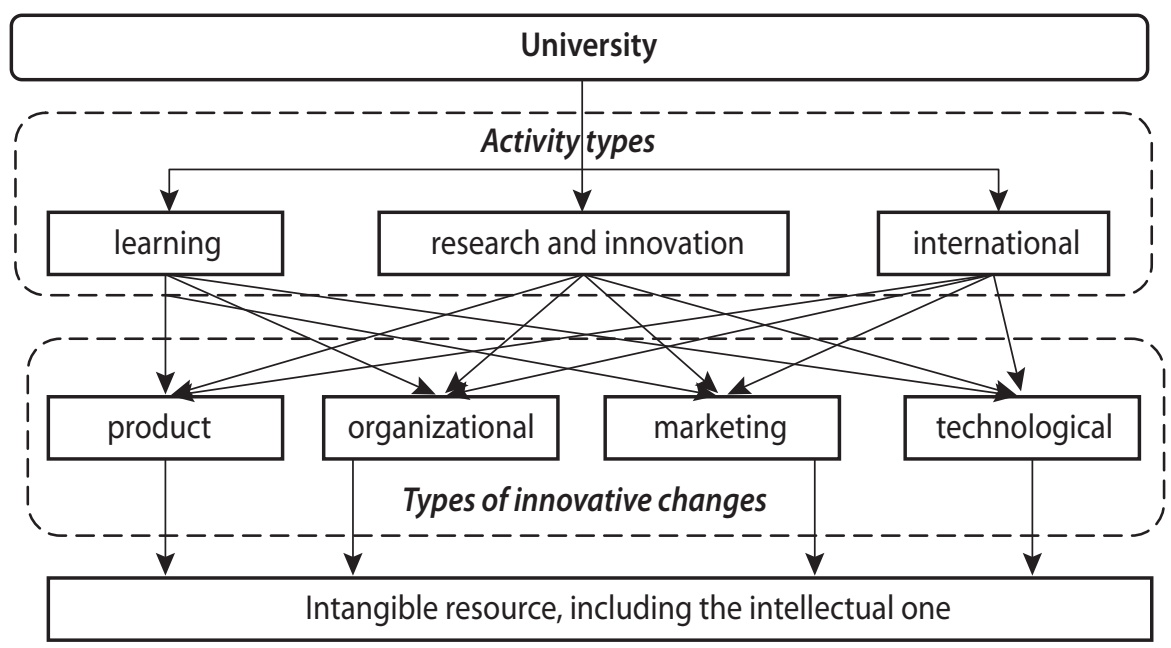

Fig. 3. Technique of analyzing the ways to implement innovative changes in the activities of domestic universities 
all levels, from determining the results of the business activity of employees, to departments, and to the company as a whole. Therefore, the KPI system is characterized by a hierarchical structure, formed on the basis of dividing higher-level indicators into components related to the activities of subordinate units / employees, but the performance level and the extent of achieving certain strategic indicators should be assessed bottom-up.

The first level of the KPI system of universities should be formed by the performance indicators of lecturers or employees of specialized structural units, so this system can also be used for the self-control and motivation of direct performers of the main activities of domestic higher education establishments. The main results of implementing the KPI system to identify the results of innovative changes in higher education establishments may be the following:

1) increase in the efficiency of universities;

2) identification and assessment of the main factors of successful activity;

3) ensuring the achievement of the desired performance through planning based on the strategic goal according to the top-down approach, and not on the basis of the existing capabilities (the bottom-up approach);

4) formation of a system of indicators and rules that ensure the goal achievement;

5) thorough assessment of performance at all management levels.

The KPIs system is widely used in business environment, especially in the field of IT, however, given the effect of the system implementation, it can and should be included in the day-to-day work of universities.

S ince the assessment result is an integrated indicator, the calculations should encompass the educational, scientific and international activities, as well as all the 4 types of innovative changes; the KPIs should be counted separately for each activity. Therefore, the first stage of developing the KPI system is the formation of a set of indicators that determine the innovativeness of activity (implementing digitalization in the learning process, the number of fundamental and applied research projects carried out, the use of dual teaching methods, the level of completeness and development of Personal Learning Environment, etc.) to identify intangible resources as a result of innovative changes in all the areas.

The next important step is normalization of the values of indicators caused by the difference between measures. It is necessary to eliminate differences in the interpretation of the content of each indicator and bring it to one measurement unit. Normalization within $[0 ; 1]$ and the introduction of a scale for transferring indicators for normalization are suggested. Thus, the maximum value should be estimated at 1 , and other values consequently recalculated proportionally [5].

The establishment of weights representing the sig- nificance level of the indicators in the system as a whole is a characteristic feature of the KPI system and one of the determining factors for its development. Establishing the significance of the elements is a complex process and should take place at the level of the department, faculty, management unit and governing body of a university. Taking this information into account, each type of innovative changes should receive indicators of change taking place in qualification requirements for direct performers at all levels, and this process requires the replacement of the linear principle of management by the functional one.

In addition, the significance of the elements should correspond to the direction of strategic development of a university. Significance coefficients should be set depending on the strategy developed at the higher education establishment and on the kind of innovations necessary to implement it. For example, indicators of the learning sphere will have higher values for higher education establishments focused on educational activity; if research activity needs to be intensified, the significance of indicators of the research and innovation sphere increases, and so on. Thus, indicators of significance should be set for the educational, research and international spheres in general as part of the integrated index, as well as for the constituent indicators in these areas. The total value of the weights must also be equal to 1 .

$\mathrm{P}$ erformance evaluation of the implementation level of all the types of innovations in each of the three main areas of university activity means measuring, standardizing and calculating all components related to this innovation area (e.g., the number of textbooks, relevant experience of the teaching staff, developments number, the number of Personal Learning Environments or PLEs), the completeness level of the PLEs, etc.), and in the long run it means the calculation of the integrated index. Thus, the general approach to evaluating performance indicators of lower-level employees, namely specialists who implement product innovation changes in the learning, research and international fields, can be presented in the form of a tuple evaluation model:

$$
P=\left\{\begin{array}{l}
\alpha=\left\{\alpha_{1} p_{1} ; \alpha_{2} p_{2} ; \ldots \alpha_{n} p_{n}\right\} \\
\beta=\left\{\beta_{1} p_{1} ; \beta_{2} p_{2} ; \ldots \beta_{n} p_{n}\right\} \\
\gamma=\left\{\gamma_{1} p_{1} ; \gamma_{2} p_{2} ; \ldots \gamma_{n} p_{n}\right\}
\end{array}\right\},
$$

where $P$ is the implementation level of product innovations;

$p_{1}, p_{2}, p_{n}-$ normalized evaluation indicators of the constituent elements of product innovations:

$p_{1}$ - the number of textbooks published;

$p_{2}$ - work experience in teaching positions, etc.;

$\alpha, \beta, \gamma-$ significance indicators (weights) for the formation of an integrated KPI index:

$\alpha$ - educational activity;

$\beta$ - research and innovative activity;

$\gamma$-international activities; 
$\alpha_{1}, \alpha_{2}, \alpha_{n}-$ significance indicators for the elements within the learning activity.

The assessment of other areas of innovation implementations is similar to this one and takes place on the basis of developing a system of indicators for each activity area at a higher education establishment:

$$
\begin{aligned}
& O=\left\{\alpha_{n} \beta_{n} \gamma_{n} o_{n}\right\} ; \\
& M=\left\{\alpha_{n} \beta_{n} \gamma_{n} m_{n}\right\} ; \\
& T=\left\{\alpha_{n} \beta_{n} \gamma_{n} t_{n}\right\},
\end{aligned}
$$

where $O$ is the implementation level of organizational innovations;

$M$ - the implementation level of marketing innovations;

$T$ - the implementation level of technological innovations.

$\mathrm{S}$ ince the KPI system is formed on the basis of strategies adopted by higher education establishments, let's consider the results of studying current development strategies of the abovementioned universities as to their implementation of innovative changes and formation of intangible resources. Product innovations are the introduction of services that are new or significantly improved in terms of their properties or uses. It is established that the formation of intangible resources regarding this innovation type is characterized by the lowest number and diversity, as it mainly includes developments in the form of a commodity. However, copyright on these implementations, their patenting and licensing creates an intellectual resource as a result of $R \& D$. In addition, among product innovations one should mention the defining type of innovative changes related to educational activities, that is, the development of education programs on an interdisciplinary basis (Taras Shevchenko Kyiv National University, Sumy State University, National Technical University "Kharkiv Polytechnic Institute", State Institution of Higher Education "Uzhgorod National University", Vadym Hetman Kyiv National Economic University). This approach allows for the training of highly qualified specialists with the best set of competencies, who can better meet both the labor market demand and the requirements for innovation.

One of the components of intangible resources management is the stage of their formation at an enterprise. And at this stage, due to regulatory requirements, it is necessary to identify intangible resources and transform them into the "intangible assets" of an enterprise. Thus, a significant part of intangible resources is overseen by the management system, as at the present development stage of enterprise management systems, it is "intangible assets" that are subject to management. However, it should be noted that due to the specificity of intangible assets, it is necessary to transform approaches to their accounting and management.

Intangible resources of enterprises are formed as a result of the costs incurred by enterprises in the process of intellectual and innovative activities. A significant part of the expenses of an enterprise is made up by expenditures, meaning they don't create any assets or resources. This is due to the time lag between a long research and development process needed to bring the costs incurred to the product form and the economic benefits received from intangible resources to be thus formed. After all, the development of an idea is just the first stage of the formation of an innovative product, and this stage is the most complex, but at the same time the most important one in innovations development. But it is while implementing innovations in any form by the company, while developing the life cycle that an idea provides the greatest profit to the company [3]. Therefore, the foundation of the information base for effective management decisions is made through systematizing the process of formation and acceptance of intangible resources. It should be noted that the concepts of "intangible assets" and "intangible resources" should be separated off. Due to the existing regulatory restrictions, the object of financial accounting is the "intangible assets" category, but the object of management and administrative accounting should currently be "intangible resources".

$\mathrm{T}$ The process of intangible resource management involves the formation of various approaches to accumulating intellectual resources as a result of innovation. Interaction with the sphere of higher education plays an important role in this process. Higher education establishments determine the general intellectual potential of society and the possibility for its involvement in innovation processes. In addition, universities as centers of scientific thought can be involved in conducting $R \& D$ for enterprises, thus playing a part in the formation of intangible resources. Therefore, the development level of higher education establishments and their innovative activities occupy a strategic position in the system of national innovation policy and make up the basis for the development and implementation of new technologies and economic growth of both individual enterprises and the economy as a whole.

Organizational innovations in the activities of higher education establishments consist in developing new methods and forms of organizing all types of university activities, improving their organizational structure as for management systems, and using available resources. Analysis of development concepts shows that organizational innovations are the most common and most numerous ones among domestic universities. In educational activities, such implementations mainly relate to the involvement of stakeholders in the educational process and the development of curricula in accordance with current trends in the labor market and with the stakeholders' interests. The implementation area of such innovations is the development of new popular specialties by almost all the universities in question, or adaptation of the existing specialties to the employers' requirements 
and to the trends in the business environment, while using labor market monitoring for both the development and adaptation. Most universities expand the role of stakeholders in designing educational programs and involve them in planning (Taras Shevchenko Kyiv National University, Igor Sikorsky Kyiv Polytechnic Institute, National Technical University "Kharkiv Polytechnic Institute", Vadym Hetman Kyiv National Economic University), direct implementation or evaluation (Ivan Franko Lviv National University, Sumy State University, Lviv Polytechnic National University, Simon Kuznets Kharkiv National University of Economics) of educational process. The introduction of a joint educational process aims to promote the formation of the top-level knowledge and competencies, which in the future will be involved in the formation of human capital and intellectual resources of economic entities.

I nvolvement of stakeholders can be traced within the organizational innovations in the research and innovation activities of higher education establishments. The technology of such changes is cooperation with business representatives in conducting research on a contract basis or in areas sponsored by the state budget in order to determine the highly-demanded research areas and increase the prospects for commercializing R\&D. The most widespread forms of such interaction are research centers and schools (Simon Kuznets Kharkiv National University of Economics, Lviv Polytechnic National University, and National Technical University "Kharkiv Polytechnic Institute”), startups (Lviv Polytechnic National University, V.N. Karazin Kharkiv National University, State Institution of Higher Education "Uzhgorod National University", and Igor Sikorsky Kyiv Polytechnic Institute). However, a successful implementation of applied developments and their results requires an innovative ecosystem, i.e. a network comprising a university together with innovative enterprises, investors, and innovation centers. The development of such an ecosystem is only taking place on the basis of Igor Sikorsky Kyiv Polytechnic Institute, while other higher education establishments of Ukraine have nothing more than just some elements of such systems.

As for the international aspect of the activities of the higher education establishments in question, these universities implement organizational innovations in the international cooperation area in order to accumulate intellectual resources, taking into account global experience in education and research. The implementation technologies for this type of innovative change are the development of educational programs in foreign languages, joint and double degree programs, programs for international academic mobility and internships, participation in international projects (among the most common are Horizon 2020 and Erasmus+).

Marketing innovations in the activities of higher education establishments generally include the introduction of new methods for positioning, promoting and pricing educational services or $R \& D$ conducted at a university in the market environment. The marketing innovations in the field of education, which are stated in the development concepts, are the following: the organization of career guidance activities aimed at attracting more gifted youth and improving the learning process at universities. These changes are implemented by organizing winter and summer schools (Taras Shevchenko National University, Lviv Polytechnic National University, Simon Kuznets Kharkiv National University of Economics) and pre-university training centers (Sumy State University, National Technical University "Kharkiv Polytechnic Institute", V.N. Karazin Kharkiv National University, Simon Kuznets Kharkiv National University of Economics). Less developed approaches are: introducing special courses for training school leavers for the External Independent Evaluation, opening camps with vocational guidance, developing cooperation with the Junior Academy of Sciences and introducing university centers of R\&D creativity for schoolchildren.

A mong the approaches to introducing marketing innovations in scientific and innovative activities, the main one is making the research results known by participating and organizing scientific and practical conferences, exhibitions, forums, festivals, etc., and this approach is widely used by all universities. Some universities use unique approaches to promoting the research results, e.g. by involving the media and holding exhibitions (Taras Shevchenko National University, Sumy State University), organizing competitions for startup projects and business ideas (Sumy State University, Uzhhorod National University). The growth of the number of approaches to marketing scientific and innovative activities of higher education establishments and their intensification will sooner or later improve the image of universities and expand the universities' partnership bases in the scientific and business environment, thus creating grounds for intangible resources and internally generated goodwill.

Another type of innovative change mentioned in the development concepts is the publication of scientific results in journals included in international databases (Web of Science, SCOPUS) contributing to the international dissemination of knowledge and indicating a high quality of human capital and intellectual resources. In addition, this approach promotes the development of new ideas and, as a result, ideological innovations, which in the future can be involved in the development of product innovations.

Marketing innovations within the international activity mainly consist of joining international organizations and associations, and activities to improve the positions in the international rankings of universities. This approach can be traced in most of the development strategies announced by the higher education establishments in question. 
Technological innovation in universities lies in the introduction of fundamentally new or improved ways of providing both educational and research services. The result of analyzing the development strategies of various Ukrainian higher education establishments shows that their educational area is subject to regular updating the content of educational programs in order for them to acquire signs of innovation, competitiveness, and interdisciplinarity in accordance with the changes in the list of specialties. In this way universities form a unique intellectual and information resource. In this area, it is necessary to highlight the replacement of traditional forms of educational activities with innovative methods, including blended, distance, and dual learning (found in most higher education establishments). However, in the context of dynamic digitalization of the economy, the role of the most promising, significant and widespread technological innovation in education is played by the introduction of different types of IT technologies. Such innovations are implemented in the following ways: the development of electronic documents circulation (Ivan Franko Lviv National University, National Technical University of Ukraine "Igor Sikorsky Kyiv Polytechnic Institute”, Sumy State University, National Technical University "Kharkiv Polytechnic Institute", V. N. Karazin Kharkiv National University, Simon Kuznets Kharkiv National University of Economics), introduction of educational platforms, automated training courses and learning systems of various types (National Technical University of Ukraine "Igor Sikorsky Kyiv Polytechnic Institute", Sumy State University, National Technical University "Kharkiv Polytechnic Institute", Lviv Polytechnic National University, Simon Kuznets Kharkiv National University of Economics, State Institution of Higher Education "Uzhgorod National University").

$\mathrm{D}$ ue to analyzing development strategies a range of technological innovations have been identified, which relate to innovations in the process of financing activities and to all areas of the work of higher education establishments, in general. The main trend here is the transition from receiving funds from the state budget and individuals to using models involving third-party sources and the commercialization of universities' activities. Thus, funding is introduced through fundraising (Sumy State University, V. N. Karazin Kharkiv National University, State Institution of Higher Education "Uzhgorod National University"), grants (Sumy State University, National Technical University "Kharkiv Polytechnic Institute", Lviv Polytechnic National University, V.N. Karazin Kharkiv National University, Simon Kuznets Kharkiv National University of Economics, State Institution of Higher Education "Uzhgorod National University"), commercialization of university's developments and research to order (Sumy State University, National Technical University "Kharkiv Polytechnic Institute", Lviv Polytechnic National University, Simon Kuznets Kharkiv National University of Economics). Thus, the amount of R\&D funding is increas- ing, which will help to expand the formation of intellectual resources by Ukrainian universities.

\section{CONCLUSIONS}

Thus, the accumulation of intellectual resources becomes a determining factor in the competitiveness of the national economy and individual enterprises. The formation of such a resource is directly influenced by the development level of the higher education system in the country and the efforts taken by universities to implement innovations in their activities. However, it is necessary to assess the maturity level of intangible resources and the achievement level of strategic objectives. To improve the management process, it is suggested to identify and assess the intangible resources formed by introducing the KPI system in the general strategy of a higher education establishment.

On the basis of the innovative development strategies of the leading higher education establishments in Ukraine, approaches to introducing innovative changes in the fields of organizational, marketing, technological, and product innovations in the universities' activity have been revealed. In addition, each of these approaches is observed in the educational, scientific and international activities of universities. Such innovative changes cause the formation of intellectual resources that can be transformed into the intangible resources of enterprises and involved in economic activities. However, the development level of the considered innovative changes is not high. None of the universities analyzed introduces innovations of unique technologies or products, etc., and the formation of innovative ecosystems is still at an early stage.

\section{LITERATURE}

1. Київський національний університет імені Тараса Шевченка. Стратегічний план розвитку Університету на період 2018-2025 року. URL: http://www.univ. kiev.ua/pdfs/official/Development-strategic-plan.pdf Концепція інноваційного розвитку ДВНЗ «Ужгородський національний університет» на 2015-2025 рр. Ужгород, 2016. URL: https://www.uzhnu.edu.ua/uk/ infocentre/get/8662

2. Лабунська С. В., Собакар М. В. ЗВО як платформа для розробки інноваційного продукту: на прикладі удосконалення методичних підходів до управління витратами інноваційної діяльності підприємства. Науковий погляд: економіка та управління. 2020. № 3. C. $145-152$.

DOI: https://doi.org/10.32836/2521-666X/2020-69-24

3. Львівський національний університет імені Івана Франка. Стратегія 2020. URL: https://www.Inu.edu. ua/wp-content/uploads/2016/07/2016-strategy.pdf Раєвнєва О. В., Малишко Є. О., Бровко О. І. Фактори конкурентоспроможності закладів вищої освіти України. Бізнес Інформ. 2020. № 12. С. 109-116. DOl: https://doi.org/10.32983/2222-4459-2020-12-109-116

4. Стратегічний план розвитку Львівської політехніки до 2025 року. URL: https://lpnu.ua/2025 
5. Стратегічний план розвитку НТУ «ХП|» на 2019-2025 роки. URL: https://www.kpi.kharkov.ua/ukr/ntu-hpi/ strategichnyj-plan-rozvytku-ntu-hpi-na-2019-2025roky/

6. Стратегічний план розвитку Сумського державного університету на 2020-2026 роки : проєкт. Суми, 2019. URL: https://news.sumdu.edu.ua/ images/announcements/2019/2019-10-28/SumDUStrategy-2026.pdf

7. Стратегічний план розвитку Харківського національного економічного університету на 2013-2020 роки, Харків. 2013. URL: https://www.hneu.edu.ua/ wp-content/uploads/2018/10/Strategic-Plan-HNEU2013-2020-years.pdf

8. Стратегія розвитку ДВНЗ «Київський національний економічний університет імені Вадима Гетьмана» на 2016-2020 роки. Київ, 2016. URL: https://kneu.edu. ua/userfiles/general_information/sr2016_2020.PDF Стратегія розвитку Каразінського університету на 2019-2025 роки. URL: https://www.univer. kharkov.ua/docs/work/strategiya-rozvytkuuniversitetu-2019-2025-2.pdf

9. Стратегія розвитку Національного Технічного Університету України «Київський політехнічний інститут імені Ігоря Сікорського» на 2020-2025 роки : проект. Київ, 2020. URL: https://osvita.kpi.ua/sites/ default/files/downloads/2020-2025-strategy.pdf Oslo Manual: Guidelines for Collecting and Interpreting Innovation Data. 3rd Edition OECD. URL: https://www. oecd-ilibrary.org/docserver/9789264013100-en.pdf?e xpires $=1598953711 \& i d=i d \& a c c n a m e=$ guest $\&$ checksu $\mathrm{m}=7$ FBA97BA2FEE2228B1581BA8A79F913D

10. The Global Competitiveness Reports 2011-2019 / World Economic Forum. URL: https://www.weforum. org/reports/the-global-competitiveness-report-2020 The Global Innovation Index Reports for 2011-2020. URL: https://www.wipo.int/publications/en/series/ index.jsp?id=129

\section{REFERENCES}

"Kontseptsiia innovatsiinoho rozvytku DVNZ «Uzhhorodskyi natsionalnyi universytet» na 2015-2025 rr." [The Concept of Innovative Development of Uzhhorod National University for 2015-2025]. Uzhhorod, 2016. https://www.uzhnu.edu.ua/uk/infocentre/get/8662

"Kyivskyi natsionalnyi universytet imeni Tarasa Shevchenka. Stratehichnyi plan rozvytku Universytetu na period 2018-2025 roku" [Taras Shevchenko National University of Kyiv. Strategic Development Plan of the University for the Period 2018-2025]. http://www.univ.kiev. ua/pdfs/official/Development-strategic-plan.pdf

"Lvivskyi natsionalnyi universytet imeni Ivana Franka. Stratehiia 2020" [Ivan Franko National University of Lviv. Strategy 2020]. https://www.Inu.edu.ua/wp-content/uploads/2016/07/2016-strategy.pdf

Labunska, S. V., and Sobakar, M. V. "ZVO yak platforma dlia rozrobky innovatsiinoho produktu: na prykladi udoskonalennia metodychnykh pidkhodiv do upravlinnia vytratamy innovatsiinoi diialnosti pidpryiemstva" [HEI as a Platform for Development of an Innovative Pro- duct: On the Example of Improvement of Methodological Approaches to Management of Enterprise's Innovative Activities Costs]. Naukovyi pohliad: ekonomika ta upravlinnia, no. 3 (2020): 145-152. DOI: https://doi.org/10.32836/2521-666X/2020-69-24

"Oslo Manual: Guidelines for Collecting and Interpreting Innovation Data. 3rd Edition OECD". https://www. oecd-ilibrary.org/docserver/9789264013100-en.pdf?e xpires $=1598953711 \& i d=i d \& a c c n a m e=$ guest $\&$ checksu m=7FBA97BA2FEE2228B1581BA8A79F913D

Raievnieva, O. V., Malyshko, Ye. O., and Brovko, O. I. "Faktory konkurentospromozhnosti zakladiv vyshchoi osvity Ukrainy" [The Factors of Competitiveness of the Higher Education Institutions of Ukraine]. Biznes Inform, no. 12 (2020): 109-116.

DOl: https://doi.org/10.32983/2222-4459-2020-12-109-116

"Stratehichnyi plan rozvytku Kharkivskoho natsionalnoho ekonomichnoho universytetu na 2013-2020 roky“ [Strategic Development Plan of Kharkiv National Economic University for 2013-2020]. Kharkiv. 2013. https:// www.hneu.edu.ua/wp-content/uploads/2018/10/ Strategic-Plan-HNEU-2013-2020-years.pdf

"Stratehichnyi plan rozvytku Lvivskoi politekhniky do 2025 roku" [Strategic Development Plan of Lviv Polytechnic until 2025]. https://lpnu.ua/2025

"Stratehichnyi plan rozvytku NTU «KhPI» na 2019-2025 roky" [Strategic Development Plan of NTU "KhPI" for 2019-2025]. https://www.kpi.kharkov.ua/ukr/ ntu-hpi/strategichnyj-plan-rozvytku-ntu-hpi-na2019-2025-roky/

"Stratehichnyi plan rozvytku Sumskoho derzhavnoho universytetu na 2020-2026 roky : proiekt" [Strategic Development Plan of Sumy State University for 20202026: Project]. Sumy, 2019. https://news.sumdu.edu. ua/images/announcements/2019/2019-10-28/SumDU-Strategy-2026.pdf

"Stratehiia rozvytku DVNZ «Kyivskyi natsionalnyi ekonomichnyi universytet imeni Vadyma Hetmana» na 20162020 roky" [Development Strategy of Vadym Hetman Kyiv National Economic University for 2016-2020]. Kyiv, 2016. https://kneu.edu.ua/userfiles/general_information/sr2016_2020.PDF

"Stratehiia rozvytku Karazinskoho universytetu na 20192025 roky" [Development Strategy of Karazin University for 2019-2025]. https://www.univer.kharkov.ua/docs/work/strategiya-rozvytku-universitetu-2019-2025-2.pdf

"Stratehiia rozvytku Natsionalnoho Tekhnichnoho Universytetu Ukrainy «Kyivskyi politekhnichnyi instytut imeni Ihoria Sikorskoho» na 2020-2025 roky : proekt" [Development Strategy of the National Technical University of Ukraine "Kyiv Polytechnic Institute named after Igor Sikorsky" for 2020-2025: Project]. Kyiv, 2020. https:// osvita.kpi.ua/sites/default/files/downloads/20202025-strategy.pdf

"The Global Competitiveness Reports 2011-2019". World Economic Forum. https://www.weforum.org/reports/ the-global-competitiveness-report-2020

"The Global Innovation Index Reports for 2011-2020". https://www.wipo.int/publications/en/series/index. jsp?id=129 